\title{
SPECIES COMPOSITION AND DIVERSITY OF TIDAL. TRAP NET CATCHES IN THE WATERS OF INDRAGIRI HILIR, RIAU, INDONESIA
}

\author{
Badrudin*), Bambang Sumiono"), and T.S. Murtoyo*)
}

\begin{abstract}
The coastal waters of the eastern part of Indragiri Hilir, Riau, which are mostly estuarine, are influenced by the huge fresh water discharge and are usually fertile. The existence of dense tidal trap net fisheries along the coastline could affect its biodiversity, as these areas usually provide a nursery ground. From a survey carried out in October-November 1998, species composition of catches and biodiversity indices including: Richness indices, Diversity indices, Diversity numbers, and Evenness indices have been calculated. The catch composition of gombang nets at Concong Luar was dominated by juvenile of bombay duck (Harpodon nehereus), hair-fin anchovy (Setipina spp.), white pomfret (Pampus argenteus), and small size shrimp (Parapenaeopsis stylifera). The catch of jermal at Sei Belah was dominated by anchovies (Stolephorus spp.), while that of sero nets at Sei Laut was dominated by the juvenile of banana shrimp (Penaeus merguiensis), and brown shrimp (Parapenaeopsis stylifera and P. sculptilis). The catch of togo at Kuala Enok was dominated by small shrimps of Acetes spp. Biodiversity indices obtained from calculation and analysis provide values can be used as baseline data for further study
\end{abstract}

KEYWORDS: biodiversity, tidal trap net

\section{INTRODUCTION}

Indonesia, with the area of only $1.3 \%$ of the world's land area, possesses up to $17 \%$ of the total number of species found in the world. Indonesia has already been described as a 'megadiversity' country and yet much of its marine habitat has yet to be surveyed. As $70 \%$ of the Indonesian area consists of water, abundant and diverse marine resources leading to high biodiversity are expected (Watson \& Purbasari, 1993). Whether this potential biodiversity can increase the prosperity of the country in the future will depend on the capability of the people to exploit and manage these biodiversity resources now.

The preservation of biodiversity became a major concern at the end of the $20^{\text {th }}$ century. However, little attention has been focused on marine biodiversity due to its remote nature, the difficulty of monitoring and studying marine habitats and the complexity of marine environments. Increasing human intervention on different ecosystems has led to the extinction of a number of higher vertebrates and an unknown quantity of lower taxonomic groups (Perez \& Mendoza, 1998).

Data and information on biodiversity indices provide basic knowledge for the sustainable exploitation and management of biodiversity resources. Biodiversity is important because it maintains life as we know it. The loss of genetic or biological diversity weakens a population's ability to adopt to environmental change. Because biological and physical pro- cesses are interactive, losses of biological diversity may also precipitate further environmental change (Anonymous, 1993).

Information on diversity indices can be used to characterize species abundance relationships in communities (Ludwig \& Reynold, 1988). Diversity is composed of two distinct components: (1) the total number of species depicting species richness, and (2) evenness, i.e. how the abundance data are distributed among the species. The index that attempts to combine both species richness and evenness into a single numerical value in this paper is called the diversity index.

This paper provides a 'baseline study' as an effort to obtain information on diversity catches of four types of tidal trap net operated in the estuarine waters along the coast of Indragiri Hilir, Riau. With the assumption that these catch samples were proportional with the community available at the time of survey, these diversity indices of catches represent the diversity of fish communities along the coast of Indragiri Hilir, Riau.

\section{MATERIALS AND METHODS}

The survey area of Riau province belongs to the district of Indragiri Hilir. Geographically, the eastern waters of this district can be depicted from the equator to the latitude $01^{\circ} 00^{\prime} S$ and between $103^{\circ} 00^{\prime}-104^{\circ} 00^{\prime}$ $E$ (Appendix 1). The water mass along the coast is influenced by three large rivers from the north to the

\footnotetext{
" Researcher at the Research Institute for Marine Fisheries, Muara Earu

r) Assessment Institute for Agriculture Technology, Central Java
} 
south, i.e.: Kampar, Indragiri and Batanghari rivers with a number of small rivers: Cenako, Gangsat, Reteh, and Tungkal. These large and small river discharges provide a substantial contribution to the fertility of the waters. In every stage of the life cycles of penaied shrimps and other demersal fishes, especially at the larval and juvenile stages, the availability of fresh water discharge will be needed to support their survival (Silas et al., 1984).

Before the implementation of Presidential Decree No.: 39/1980, the waters of Indragiri Hilir, as an extension of Jambi Bay, provided a good fishing ground for shrimp, mainly for trawlers owned by the state enterprise, Karya Mina, based in Tanjung Pinang. Some trawlers marked SMF (Singapore-Malay Fishing) company were often observed in these waters and some of them were arrested by the navy. In the long term, the operation of the most active fishing gear using non selective net like trawls will undoubtedly affect the diversity of fish resources in this area.

The most common type of tidal trap nets found along the coast of Indragiri Hilir were gombang net, kelong, jermal, and togo. These fishing gears were set in the tidal zone. The cod ends of the net were usually taken twice per day. The operation of the huge amount of tidal trap nets in a tidal zone will directly affect the survival rate of most juvenile fish as these areas usually provide a nursery ground. Schematic description of the four nets are presented in Figure 2 (Appendix 3)

Catch rate data (catch/unit net/haul) were obtained from a partial survey on fish catches by gombang net, jermal, kelong, and togo, some typical and common tidal trap nets operated along the eastern part of Sumatera. These four types of trap used the same type of net called waring with the mesh size of $5 \mathrm{~mm}$ stretched mesh.

The survey was conducted in October-November 1998 along the coastal waters of Indragiri Hilir, Riau, and reported elsewhere by Sumiono \& Murtoyo (1998). Catch of gombang net was collected from the waters of Concong Luar, catch of jermal net from Sei Belah, catch of kelong net from Sei Laut and catch of togo net from Kuala Enok. These catches were sorted up to the lowest possible taxonomic level, weighed and counted individually

Biodiversity description of the catch includes the calculation of Richness indices, Diversity indices and Evenness indices, following Ludwig \& Reynold (1988). Richness indices include Margalef index: $\mathrm{R}_{1}=(\mathrm{S}-1) /$ In ( $n$ ); Menhinick index: $R_{2}=S / O ̈ n$, where $S=$ number of species (species group) in a community, and $n$ $=$ total number of individual observed. Diversity indices include Simpson (I) and Shannon $(H)$, Diversity numbers: $N_{0}$ is the number of all species in the sample, regardless of their abundance; $N_{1}$ is the measure of the abundant species and $\mathrm{N}_{2}$ is the number of very abundant species. $\mathrm{N}_{1}$ will always be intermediate between $N_{0}$ and $N_{2}$. The formula of the Simpson index: $I=a ̊\left[\left(n_{i}\left(n_{-}-1\right) /(n(n-1)]\right.\right.$ and the Shannon index: $H=a\left[\left(n_{i} / n\right) \ln \left(n_{i} / n\right)\right]$, where $n$ is the total number of individual and, $n$ is the number of species $i$. Calculations of Evenness indices include: Pielou, $E_{1}=[H / l n$ (S)]; Sheldon, $E_{2}=\left(e^{H} / S\right)$; Heip, $E_{3}=\left[\left(e^{H}-1\right) /(S-\right.$ 1) ]; Hill, $E_{4}=\left[(1 / 1) ! \mathrm{e}^{\mathrm{H}}\right]$; and modified Hill, $E_{5}=$ $\left\{[(1 / /)-1] /\left(e^{H}-1\right)\right\}$.

\section{RESULTS AND DISCUSSION}

\section{Species Composition}

The catch of gombang net in the area of Concong Luar in terms of weight was dominated by the bombay duck (Harpondon nehereus), hair-fin anchovy (Setipina spp., Engraulidae) and several species of crabs. In terms of number, the most dominant fish caught were juvenile anchovy (Setipina spp.), juvenile of white pomfret (Pampus argenteus) and small size brown shrimp (Parapenaeopsis stylifera). The high occurrence of anchovy was likely similar to that reported by James \& Probyn (1989), where the anchovy was capable of preying upon a wide spectrum of particle size by employing its gill raker mechanism either in conjunction with particulate feeding or by switching to filter feeding mode

In the waters of Sei Belah, the catch of jermal both in terms of weight and numbers of individuals was dominated by anchovies (Stolephorus spp.). Other dominant fish like those in Sei Belah, were caught in a relatively small amount in the waters of Concong Luar. The same situation was also observed in the catch of kelong in Sei Laut. In those waters, the dominant catch was mostly juvenile shrimps, such as white shrimp (Penaeus merguiensis), brown shrimp (Parapenaeopsis stylifera and $P$. sculptilis), some small size shrimp (mysids, Acetes spp.), and yellow shrimp (Metapenaeus lysianasa).

The fish caught were diverse, although both their weight and numbers were very small. Similar to the catch in Sei Belah that was dominated by the anchovies, the catch of togo in the waters of Kuala Enok was dominated by mysids (Acetes spp.) (Table 1). The fact that most catches were relatively low in weight, but quite high in terms of numbers and consequently small sized individuals, indicates that these waters, as most estuarine areas, provide a nursery ground.

The estuarine ecosystem, which is largely hidden from human eyes, is very complex with respect to its species composition as well as processes occuring 
Table 1. Catch composition of gombang net at Concong Luar, jermal at Sei Belah, kelong at Sei Laut and togo at Kuala Enok

\begin{tabular}{|c|c|c|c|c|c|c|c|c|}
\hline \multirow{2}{*}{$\begin{array}{c}\text { Fish species") } \\
\text { (Species group) }\end{array}$} & \multicolumn{2}{|c|}{$\begin{array}{l}\text { Gombang net } \\
\text { Concong Luar }\end{array}$} & \multicolumn{2}{|c|}{$\begin{array}{l}\text { Jermal net } \\
\text { Sei Belah }\end{array}$} & \multicolumn{2}{|c|}{$\begin{array}{l}\text { Kelong net } \\
\text { Sei Laut }\end{array}$} & \multicolumn{2}{|c|}{$\begin{array}{c}\text { Togo net } \\
\text { Kuala Enok }\end{array}$} \\
\hline & $\left.W^{\star \star}\right)$ & $\left.N^{* *}\right)$ & $\mathbf{W}$ & $\mathbf{N}$ & $\mathbf{W}$ & $\mathbf{N}$ & $\mathbf{w}$ & $\mathbf{N}$ \\
\hline Arius caelatus & 1.8 & 716 & - & - & 3.8 & 590 & 0.3 & 3 \\
\hline Chorinemus sp. & - & 386 & 3.4 & 1 & - & - & - & - \\
\hline Diodontidae & 1.4 & - & 1.6 & 11 & 0.3 & 10 & 0.04 & 2 \\
\hline Fistularia sp. & - & 55 & - & - & - & - & - & - \\
\hline Formio niger & 0.3 & - & - & - & - & - & - & - \\
\hline Gerres spp. & - & 1,950 & - & - & 0.3 & 100 & - & - \\
\hline Harpondon nehereus & 15 & - & 2 & 53 & - & - & - & - \\
\hline Hemirhampus spp. & - & - & 0.1 & 11 & - & - & - & - \\
\hline Lates calcarifer & - & 623 & 2.5 & 1 & - & - & - & - \\
\hline Illisha spp. & 2.1 & - & 0.4 & 42 & - & - & - & - \\
\hline Mugillidae & - & - & 0.1 & 11 & 0.6 & 80 & - & - \\
\hline Muraenesocidae & 1 & 243 & - & - & 2.5 & 60 & - & - \\
\hline Pampus argenteus & 8.3 & 3,000 & 0.3 & 11 & - & - & - & - \\
\hline Plotosus spp. & - & - & - & - & 1.5 & 60 & - & - \\
\hline Polynemidae & 0.8 & 75 & 1.6 & 32 & 0.4 & 40 & - & $=$ \\
\hline Scatophagus argus & - & - & - & - & 3 & 200 & 0.02 & 2 \\
\hline Setipina spp. & 9.8 & 3,329 & 0.4 & 179 & 0.1 & 20 & - & - \\
\hline Sciaenidae & 0.2 & 64 & 1 & 53 & 1 & 120 & 0.03 & 2 \\
\hline Secutor ruconius & - & - & 0.1 & 21 & - & - & 0.03 & 5 \\
\hline Soleidae & 3.6 & 138 & - & - & 1 & 100 & - & - \\
\hline Stolephorus spp. & 1 & 718 & 10.5 & 6,778 & 0.1 & 20 & 0.23 & 21 \\
\hline Therapon spp. & - & " & - & - & 0.1 & 10 & - & - \\
\hline Trichiurus lepturus & 1.7 & 235 & - & - & 0.8 & 20 & - & - \\
\hline T. savala & 0.8 & 83 & 0.4 & 84 & - & - & - & - \\
\hline Thryssa spp. & 3.1 & 417 & 0.9 & 105 & 0.2 & 10 & - & - \\
\hline Squids & 0.2 & 40 & 0.1 & 11 & - & - & - & - \\
\hline Cuttlefish & - & - & - & - & - & - & 0.02 & 2 \\
\hline Crabs & 8.7 & 2212 & 0.2 & 42 & 1.3 & 160 & - & - \\
\hline Gastropods & - & - & - & - & 1.1 & 150 & - & $=$ \\
\hline Penaeus marguinensis & 0.9 & 733 & 0.9 & 179 & 14.2 & 6,390 & - & - \\
\hline Metapenaeus lysianasa & 1.3 & 460 & - & - & 5 & 1,769 & 1.5 & 378 \\
\hline M. dobsoni & 0.1 & 20 & - & - & - & - & - & - \\
\hline Parapenaeopsis stylifera & 7 & 2,944 & 0.1 & 21 & 9.6 & 3,200 & - & - \\
\hline P. sculptilis & 3.5 & 1,153 & 0.1 & 21 & 15 & 3,535 & - & - \\
\hline Acetes spp. & 0.6 & 935 & - & - & 1.2 & 2,040 & 4.5 & 7,013 \\
\hline Apheidae & 2.1 & 785 & - & - & - & - & - & - \\
\hline Squilla spp. & 1.7 & 369 & 0.2 & 11 & 1 & 30 & - & - \\
\hline Miscellanous & 24.3 & 7,604 & - & - & 3.5 & 1,460 & 0.75 & 312 \\
\hline Total & 102.3 & 29,287 & 27 & 7,678 & 67.6 & 20,174 & 7.4 & 7,740 \\
\hline
\end{tabular}

Notes:

-) see Table 3 for local and English names.

*) $W=$ weight in $\mathrm{kgs}$.

$\mathrm{N}=$ numbers (individuals) 
within it. It consists of varying numbers of different species of animals and plants, processes altering the distribution, abundance, and other properties of this biota, and the physical and chemical environment which change in spatial and temporal manner

Some important factors affecting the abundance of fish resources are fishing activities, environmental changes, pollution and human activities other than fishing, such as biological and chemical waste disposal. Other important aspects such as variability, biological interaction and environmental factors are discussed below

Variability of catch composition among the four areas was observed. The highest catch rate and number of species or species groups occurred in Concong Luar, while the lowest catch and number of species were occurred in the catch at Kuala Enok. This is difficult to explain without data on water quality and bottom conditions. Some important aspects that need to be observed further in the fish schooling behaviour include variability which is caused by (a) external factor that affect directly or indirectly the resources and (b) internal complexities of the systems in the community as a reaction to the external variability (Steele, 1984). With the two interconnected points above, it is obvious that the available community systems in certain waters are not simple. Explaining the causes of the existence and the absence of species in a certain place is not easy, and it will need long and appropriate historical time series data. In connection with the survey area, the reason for the variability in catches among these estuarine zones has not been explicitly identified. As pointed out by Baran (2000), one of the reasons is that both adults and juveniles are present in the more saline zone, while juveniles dominate in the most brackish water zones and result in lower catches.

The interaction among organisms is due to the inter-ecological relationship available in the same habitat, which is also not easy to understand, but the results can be detected. The most common interaction occurred in the form of predator-prey relationship and food competition. In relation to the life cycle of most marine organisms, the larval, post larval and juvenile stages are the most vulnerable phases of their life as most of them are prey for other bigger organisms. Penaeid shrimp larvae were often found in the stomach contents of some demersal species, such as red snappers (Desriyanti, 2000) and lizard fish (Sumiono, 2000 unpublished). An unbalanced predator-prey relationship in a community will lead to the extinction of prey organisms and finally will decrease the population of predators. Jones (1982) reported that the direct impact of predation on a certain organism will reduce the population size of prey. On the other hand, reducing the population size of a predator will lead to increasing numbers of the prey population.

At a certain phase of the life cycle some fish and shrimp populations will be very sensitive to environmental changes. The marine environment is very dynamic and most fish communities may be influenced. Interaction of fish resources with some environmental factors has been studied by many scientists. Garcia (1984) related the abundance of shrimp stock for the prediction of shrimp production in the waters of Lousiana and Gulf of Mexico to the amount of annual river discharge and fishing effort. A positive relationship of shrimp production and the amount of rainfall was reported by Staples et al., (1984) for the Gulf of Carpentaria, Australia prawn fisheries, while Penn (1984) reported the same phenomenon for shrimp fisheries in the Gulf of Texas. These findings indicate that there is a positive relationship between the amount of rainfall and the flow of river discharge which will increase the fertility of the waters and be followed by increasing populations of organisms leading to a higher biodiversity

\section{Diversity}

Some diversity indices obtained from these analyses and calculations provide single values that can be considered as 'baseline data' which can be used for comparison with further studies in the same or similar areas. Changes in these indices provide an indication of the disturbances occurring in the community environment. Comparison can also be applied horizontally from certain waters to other nearby waters.

Except for the waters of Kuala Enok with a relatively low value of richness index $\left(R_{1}=1.005\right)$, richness values for the three waters area were comparable. Compared with the other indices, the value of $N_{1}$ and $N_{2}$ of the catch of gombang net in the waters of Concong Luar and kelong in Sei Laut were outstanding. $N_{1}$ is a diversity number that shows the amount of abundance species, while $\mathrm{N}_{2}$ is the number of very abundance species or species groups. The catch composition data where the diversity number in the waters of Concong Luar $\left(N_{1}=12.680\right)$, implied that there were at least twelve abundance species or species groups and there were about eight to nine of the very abundance species (Table 2). Those species or species groups include hair-fin anchovy (Setipina spp.), white pompret (Pampus argenteus), brown shrimps (Parapenaeopsis stylifera and P. sculptilis), crabs. Apheidae, banana shrimps (Penaeus merguiensis) and marine catfish (Arius caelatus). The abundance of fish and shrimp ( ${ }^{3} 2000$ individuals) was substantial. The indices values in the waters of Sei Belah and Kuala Enok were contradictory where $\mathrm{N}_{1}$ 
Table 2. Richness indices, Diversity indices and Evenness indices of catch of four types of trap nets in the waters of Indragiri Hilir, Riau

\begin{tabular}{lccccc}
\hline \multicolumn{1}{c}{ Indices } & & $\begin{array}{c}\text { Gombang net } \\
\text { Concong Luar }\end{array}$ & $\begin{array}{c}\text { Jermal net } \\
\text { Sei Belah }\end{array}$ & $\begin{array}{c}\text { Kelong net } \\
\text { Sei Laut }\end{array}$ & $\begin{array}{c}\text { Togo net } \\
\text { Kuala Enok }\end{array}$ \\
\hline $\begin{array}{l}\text { Richness: } \\
\text { Margaleff index: }\end{array}$ & $\mathrm{R}_{1}$ & 2.43 & 2.236 & 2.236 & 1.005 \\
Menhinick index: & $\mathrm{R}_{2}$ & 0.192 & 0.24 & 0.169 & 0.114 \\
Diversity: & $\lambda$ & 0.118 & 0.781 & 0.181 & 0.825 \\
Simpson index: & $\lambda$ & 2.54 & 0.650 & 2.014 & 0.400 \\
Shannon index: $\mathrm{H}$ & $\mathrm{H}$ & 12.68 & 1.920 & 7.493 & 2.282 \\
Diversity number: & $\mathrm{N}_{1}$ & 8.506 & 1.280 & 5.525 & 1.212 \\
& $\mathrm{~N}_{2}$ & & & & \\
Evenness & $\mathrm{E}_{1}$ & 0.780 & 0.214 & 0.634 & 0.358 \\
Pielou index: & $\mathrm{E}_{2}$ & 0.488 & 0.091 & 0.312 & 0.228 \\
Sheldon index: & $\mathrm{E}_{3}$ & 0.467 & 0.046 & 0.282 & 0.142 \\
Heip index: & $\mathrm{E}_{4}$ & 0.671 & 0.667 & 0.737 & 0.531 \\
Hill index: & $\mathrm{E}_{5}$ & 0.643 & 0.304 & 0.697 & 0.165 \\
Modified hill index: & & & & \\
\hline
\end{tabular}

and $\mathrm{N}_{2}$ only around one implied that the very abundance species in each area during the survey period was represented by only one species or species groups. These were represented by anchovies (Stolephorus spp.) that were abundant in the waters of Sei Belah, banana shrimp (Penaeus merguiensis) in Sei Laut and small sized shrimp or mysids (Acetes spp.) in the waters of Kuala Enok.

\section{CONCLUSIONS}

From the above results and discussions, some important points as follows:

- A substantial tidal trap net fisheries in the area could affect survival rate of most available biota, as the area is a nursery ground

- Catches of gombang net in the waters of Concong Luar in terms of weight were dominated by juveniles of bombay duck (Harpodon nehereus), hair-fin anchovies (Setipina spp.), white pomfret (Pampus argenteus) and brown shrimp (Parapenaeopsis stylifera). In terms of number, the catch was dominated by hair-fin anchovy

- Catches of jermal net in Sei Belah were dominated by anchovies (Stolephorus spp.), while catches of kelong net in Sei Laut were dominated by the juveniles of banana shrimp (Penaeus merguiensis), brown shrimp (Parapenaeopsis stylifera and P. sculptilis), and catches of togo in Kuala Enok were dominated by very small shrimp or mysids (Acetes spp.)
- Biodiversity indices obtained from calculation and analysis can be used as baseline data for further study

\section{REFERENCES}

Anonymous, 1993. National strategy for marine biodiversity management. Technical appendix. $\ln \mathrm{R}$. A.Watson (Eds.). Marine Biodiversity Management. Final Report on Advisorship. EMDI, Min. of State for the Environment, RI and Dalhousie University, Canada. $77 \mathrm{pp}$.

Baran, E., 2000. Biodiversity of estuarine fish faunas in West Africa. Naga. The ICLARM Quarterly. Vol. 23. No.4: $4-9$.

Desriyanti, 2000. Beberapa aspek biologi dan perikanan kakap merah (Lutjanus malabaricus), yang didaratkan di Pelabuhan Tembaga, Probolinggo, Jawa Timur. Karya IImiah Praktek Akhir - Teknologi Pengelolaan Sumberdaya Perairan. Sekolah Tinggi Perikanan. $71 \mathrm{pp}$.

Garcia, S.M., 1984. Environmental aspects of penaeid shrimp biology and dynamics. In J.A.Gulland and B.J.Rothschild (Eds.). Penaeid shrimp - their biology and management. Fishing News Books Limited. England. p. 268-271.

James, A.G. and T. Probyn. 1989. The relationship between respiration rate, swimming speed and feeding behaviour in the cape anchovy, Engraulis capensis. Jour of. Exp. Mar. Biol. and Ecology. Vol.131: 81-131.

Jones, R., 1982. Ecosystems, Food Chains, and Fish Yields. In D.Pauly and G.I.Murphy (Eds.).. Theory and 
management of tropical fisheries. ICLARM-CSIRO. p. $195-239$

Ludwig, J.A., and J.F. Reynolds., 1988. Statistical Ecology. A Primer on Methods and Computing. John Wiley \& Sons. New York. 337 pp.

Penn, J.W. 1984. The behavior and catchability of some commercially exploited penaeids and their relationship to stock and recruitment. In J.A.Gulland and B.J.Rothschild (Eds.).Penaeid shrimp - their biology and management. Fishing News Books Limited. England. p. 173-186

Perez, J.F. and J.J. Mendoza. 1998. Marine fisheries, genetic effects, and biodiversity. Naga. The ICLARM Quarterly. Vol. 21. No.4: 7-14.

Silas, E.G., M.J.George, and T.Jacob., 1984. A review of the shrimp fisheries of India; a scientific basis for the management of the resources. In J.A.Gulland and B.J.Rothschild (Eds.). Penaeid shrimp - their biol- ogy and management. Fishing News Books Limited. England. p. 104-110.

Staples, D.J., W.Dall and D.J.Vance., 1984. Catch prediction of the banana prawn, Penaeus merguiensis, in the south-eastern Gulf of Carpentaria. In J.A.Gulland and B.J.Rothschild (Eds.). Penaeid shrimp - their biology and management. Fishing News Books Limited. England. p. 259-267.

Steele, J.H., (1984). Kinds of variability and uncertainty affecting fisheries. In R.M. May (Eds.). Exploitation of marine communities. Dahlem Workshop Reports. Life Sciences Research Report 32. SpringerVerlag.Berlin. 366 pp.

Watson, R. and I.A.N. Purbasari., 1993. Marine Biodiversity and Indonesia. In R. A.Watson (Eds.). Marine Biodiversity Management. Final Report on Advisorship. EMDI, Min. of State for the Environment, RI and Dalhousie University, Canada. 77 pp. 
Table 3. Scientific, local, and English names of tidal trap nets catches in the waters of Indragiri Hilir

\begin{tabular}{lll}
\hline \multicolumn{1}{c}{ Scientific name } & \multicolumn{1}{c}{ Local name } & \multicolumn{1}{c}{ English name } \\
\hline Arius caelatus & Manyung & Marine catfish \\
Chorinemus spp. & Parang-parang & Wolf herring \\
Diodontidae & Buntal & - \\
Fistularia sp. & Julung-julung & Pipe fish \\
Formio niger & Bawal hitam & Black pomfret \\
Gerres spp. & Kapas-kapas & - \\
Harpodon nehereus & Nomei & Bombay duck \\
Hemirhampus spp. & Julung-julung & - \\
Lates calcarifer & Kakap putih & Barramundi \\
Illisha spp. & Kemprit & - \\
Mugillidae & Belanak & Mullet \\
Muraenesocidae & Remang & Eel \\
Pampus argenteus & Bawal putih & White pomfret \\
Plotosus spp. & Sembilang & - \\
Polynemidae & Kuro/Senangin & Giant threadfin \\
Scatophagus argus & Blekutak & - \\
Setipina spp. & Daun bambu & Hair-fin anchow \\
Sciaenidae & Gumalah & - \\
Secutor ruconius & Peperek & Pony fish \\
Soleidae & Sembilang & Tongue sole \\
Stolephorus spp. & Teri & Anchow \\
Therapon spp. & Kerong-kerong & - \\
Trichiurus lepturus & Layur & Hairtail \\
T. savala & Layur & Hairtail \\
Thryssa spp. & Daun bambu & - \\
Squids & Cumi-cumi & Squids \\
Cuttlefish & Sotong & Cuttle fish \\
Crabs & Kepiting & Crabs \\
Gastropods & Keong & Snails \\
Penaeus merguiensis & Udang jerbung & Banana shrimp \\
Metapenaeus lysianasa & Udang krosok & Brown shrimp \\
M. dobsoni & Udang krosok & Brown shrimp \\
Parapenaeopsis stylifera & Udang krosok & Brown shrimp \\
P. sculptilis & Udang krosok & Brown shrimp \\
Acetes spp. & Udang rebon & Mysids \\
Alpheidae & Campuran & Miscellaneous \\
Squilla spp. & & \\
Miscellanous & & \\
\hline & & \\
\hline
\end{tabular}

